\title{
GOVERNMENT SUPPORT FOR UNIVERSITIES AND COLLEGES IN
} \section{GREAT BRITAIN}

\begin{abstract}
GOLLOWING last year's precedent, the University Grants Committes again prefaces its annual returns from universities and colleges in Great Britain in receipt of Treasury grants for the academic year 1960-61*, now covering 22 universities and 3 colleges, with an introduction which in effect amounts to an interim report. This note refers to the establishment of an ad hoc advisory panel to deal with proposals for the development in the universitios of studies in teaching English as a second or foreign language. Four universities have already initiated such studies and other universities have put forward proposals, but the rate of expansion is severely limited by the shortage of trained teachers and for the first years of the next quinquennium resources will be concentrated in the four universities where the studies are already established. Financial provision of $£ 10,000$ in $1962-63$ rising to $£ 70,000$ in $1966-67$ has been earmarked for these developments.
\end{abstract}

The University Grants Committee has also earmarked a sum of $£ 560,000$ in 1962-63, rising to $£ 640,000$ in $1966-67$, for support of research projects from which the Research Councils are withdrawing support at the end of the current quinquennium but which the universities consider important enough to be given priority with, or immediately after, existing commitments ahead of any new developments. Following acceptance of the recommendations of the Hayter Committee on the further development of Oriental, Slavonic, East European and African Studies, involving expenditure rising from $£ 120,000$ in 1962-63 to $£ 290,000$ in 1966-67, an interim scheme for the award of special postgraduate scholarships to commence in October 1962 has already been adopted. Discussions are already proceeding with the universities on the further allocation of these funds and nine centres for area studies have already been selected. Fourthly, the Committee has earmarked special funds, rising from $£ 185,000$ in $1962-63$ to $£ 750,000$ in 1966-67, for the development of dental schools, both for teaching and research. This will permit the intake of dental students being raised, as requested by the Government, from 620 to 940 a year.

The University Grants Committee is also discussing with the universities the meeting of two other national needs brought to its notice. First, the Government requested the Committee to consider the possibility of increasing the intake of the medical schools by 10 per cent above the level recommended by the Willink Committee and in the initial discussions it was assumed that the recurrent grants for 1962-67 would allow for a reasonable development of the medical schools. Following the Government's rejection in March of the Committee's recommendations for recurrent grants during that quinquennium, further advice was submitted to the Government in July. The new recommendations were accepted by the Government, and, in addition to capital grants of about $£ 100,000$, recurrent grants for this purpose, rising from $£ 135,000$ in $1962-63$ to $£ 245,000$ in $1966-67$, will be provided.

The second matter was raised by the Foreign Office late in the year and relates to the further development of Latin-American studies, and a committee, with Dr. J. H. Parry as chairman, has been set up to review developments in the universities in the field of Latin-American studies and to consider and advise on proposals for future developments. The University Grants Committee also

* University Grants Committee. Returns from Universities and University 1855.) Pp. xxiv +48. (London: H.M. Stationery Office, 1962.) 58. 6d. net. notes that, while the proposals originally put forward by the universities provided for the 500 additional places in University Departments of Education requested by the Ministry of Education for the next quinquennium, the funds made available under the Government's announce. ment last March fall short of the universities' and the Committee's estimates of their needs. While the Com. mittee makes no direct comment on this decision, it does not conceal its concern at the probable consequences of the decision on standards of teaching and research in the universities or on the ability of the universities to provide the number of student places desired by the Government. There will clearly be little money available for other developments during the quinquennium and, small as are the earmarked grants already mentioned, against this background the risk of distortion is greater.

Assessment of the universities' recurrent financial needs during the coming quinquennium was indeed the Committee's main concern during the year. In this connexion it points out that net expenditure on existing commitments is bound to increase, particularly in respect of salaries and building programmes, and it concludes that to meet existing commitments the universities as a whole would need a 3.5 per cent increase in grants over 1961-62 in $1962-63$ and 15.9 per cent in 1966-67. The Committee's proposals contemplate provision of places for 151,000 students by the end of the quinquennium, an increase of 36 per cent over 1961. The calculations on which the Committee's report to the Chancellor of the Exchequer on the 1962-65 building programme was based showed that if standards of admission were not raised, by 1966-67 at least, 180,000 if not 200,000 places might be required for those academically qualified. Of the 30 per cent increase to 144,500 students (compared with 111,100 in 1961-62) about two-thirds will take place in the pure and applied sciences. The respective percentages are: pure science, $41 \cdot 7$; applied science, 60.4 ; medicine, 8.4 ; dentistry, $35 \cdot 2$; agriculture and forestry, 20.9 ; veterinary science, 13.7.

For the rest, this general survey notes the establishment of a small ad hoc group to consider in principle and advise on the advantages which can be secured from a proposed grouping of postgraduate institutes and hospitals and their joint use of facilities. Furthermore, in view of the National Coal Board's intention to reduce considerably its demand for graduates in coal-mining and to concentrate its assistance to university mining departments on five instead of nine, the University Grants Committeo is participating in relevant discussions to effect this concentration without hardship to academic staff or students concerned. The Board wishes to concentrate its help in the mining departments of King's College, Newcastle upon Tyne, the University College of South Wales and Monmouthshire, the University of Nottingham, either the University of Leeds or the University of Sheffield, and in one centre in Scotland. The question of acedemic salaries is discussed at some length (this and other financial matters are considered on p. 1 of this issue of Nature).

The number of full-time students in British universities increased to 107,699 , compared with 104,009 in $1959-60$, and of these 17,925 were in the Universities of Oxford and Cambridge, 21,995 in the University of London, 42,819 in other English universities, 6,431 in the Univorsity of Wales, and 18,529 in Scottish universities. There were 11,608 students from overseas, 6,932 of whom were from within the Commonwealth, and 5,242 of whom were postgraduate. Of the full-time students 27.4 per cent were in colleges or halls of residence, 50.7 per cent in lodgings 
and 21.9 per cent at home; these figures compare with $28 \cdot 1,40.9$ and 31.0 per cent, respectively, in $1953-54$ these proportions varied widely in different universities and for men and women. In Scotland only 9.6 per cent of men and 20.0 per cent of women were in colleges or halls of residence, while $50 \cdot 7$ per cent of men and $45 \cdot 4$ per cent of women were at home.

Of full-time men students 25.4 per cent were in arts and 11.5 per cent in social studies; 25.5 per cent in science, 19.5 per cent in technology and 11.5 per cent in medicine; for women the corresponding figures are: $52.7 ; 9.4$; $21.7 ; 1.3$; and 11.2 . Of those that were 'full-time', and apart from students engaged in research or other advanced work, 27,702 were in arts, 10,115 in social studies, 21,395 in pure science, 13,597 in technology and 11,199 in medicine. Among the 17,836 advanced students, 3,551 (2,193 men) were taking postgraduate courses in teacher training; 3,326 of the others were in arts, 1,692 in social studies, 5,058 in pure science, 2,628 in technology, and 1,077 in medicine. Of full-time students 84,999 were reading for a first degree, 3,958 for a first diploma and 908 attending courses not leading to a degree or diploma; the proportion of men ( 75.5 per cent) and women (24.5 per cent) was again little changed from $1938-39(76 \cdot 7$ and $23 \cdot 3$ per cent, respectively). Of the 29,510 full-time students admitted for the first time in 1960-61, 32.7 per cent were in arts, 12.0 per cent in social studies, 26.4 per cent in pure science, 15.1 per cent in technology and 8.8 per cent in medicine, and over the past four years increases in pure science and technology have been about twice as great as in arts.

The proportion of assisted students was 82.4 per cent, as in 1959-60, which compared with 71.9 per cent in 1953-54, ranging from $92 \cdot 6$ per cent in Wales, $89 \cdot 2$ in English universities excluding those at Oxford, Cambridge and London, to $72 \cdot 8$ per cent for Scotland. There were
17,831 part-time students, 4,860 from overseas, and of these 13,478 were in English and 4,132 in Scottish institutions; 6,234 were engaged in research or other advanced work. Full-time teaching and research staff, excluding Oxford and Cambridge, increased to $12,105(11,474$ in 1959-60) and $25 \cdot 7$ per cent are now in science, 14.8 per cent in technology and 17.4 per cent in medicine. The percentage of professors was $12 \cdot 0$, readers and independent lecturers $6 \cdot 2$, senior lecturers $12 \cdot 3$, and lecturers $47 \cdot 7$. Including Oxford and Cambridge the grand total was 12,417 .

Of the recurrent increase of $£ 68,706,388$ ( $£ 59,800,092$ in $1959-60), £ 48,399,076(70 \cdot 4$ per cent) was from Treasury grants, and $£ 1,224,802$ from grants from Government departments ; $£ 6,317,603$ from fees $(9 \cdot 2$ per cent $), £ 1,963,347$ $(2 \cdot 9$ per cent) from endowments, $£ 1,577,564(2 \cdot 3$ per cent) from local authority grants, $£ 506,806$ from donations and subscriptions, and $£ 6,215,400(9 \cdot 1$ per cent) from payments for research. It is expected that the increase in students' fees will provide a further $£ 1.3$ million or 1.7 per cent of total income in 1962-63. For English, Welsh and Scottish Institutions the totals are $£ 55,506,730, £ 3,437,275$ and $£ 9,762,383$, respectively. Non-recurrent Treasury grants amounted to $£ 22,199,128$, an increase of $£ 2,346,381$ over the previous year, and of this $£ 14,576,504$ was spent on building work, $£ 2,212,152$ on professional fees, $£ 4,123,907$ on furniture and equipment and $£ 1,286,565$ on site and property purchases. Of the recurrent expenditure of $£ 67,822,988$ - an increase of $£ 9,317,916$ on $1959-60-6 \cdot 7$ per cent was spent on administration, $44 \cdot 1$ per cent on salaries and superannuation of teaching staff, $11 \cdot 2$ per cent on departmental wages, $14 \cdot 1$ per cent on departmental and laboratory maintenance, $3 \cdot 3$ per cent on repairs and maintenance of buildings and $\mathbf{9} \cdot 8$ per cent on rates, insurance, heat, light, etc. Expenditure on libraries, at

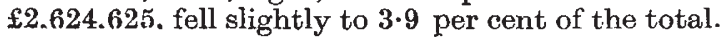

\section{SCIENTIFIC RESEARCH IN NEW ZEALAND}

\begin{abstract}
WHE report of the Department of Scientific and Industrial Research, New Zealand, for the year ended March 31, 1962, includes the Minister's Statement, the report of the Council and the Secretary's report, as well as reports from the various Divisions of the Department, the incorporated Research Associations and on grantaided research in the Cawthron Institute, Lincoln College, Massey College and the Industrial Development Department of the University of Canterbury*. Lists of publications during the year are appended to these reports and to the whole is appended the fourth annual report of the Ross Dependency Research Committee. The latter records reconnaissance geological and mapping surveys of 27,000 square miles in the Beardmore Glacier region, a unique study of temperature gradients in Lake Vanda in the Wright valley, and a new study of penguins, seals and marine biological problems in the McMurdo Sound area.

The Council's report records the adoption by the Government of the Council's proposals for changes in the basis of support by State Departments of research in the universities. Under these, State Departments will sponsor and provide funds for research units in the universities in fields of study deemed essential in the national interest and in which an outstanding man is available in the university, enter into research contracts with tho universities for specific research projects, and provide studentships in fields of science of special interest to the department concerned. Meanwhile, the Department of Scientific and Industrial Research will provide funds for the establish-
\end{abstract}

* New Zealand. Report of the Department of Scientiflc and Industrial Research for the year ended 31 March, 1962. Pp. 87. (Wellington: Government Printer, 1962.) (H.34.) ment in 1962 of research units in agricultural economics at Lincoln College and in molecular biology at the University of Auckland. The Council has also considered strengthening the Auckland Industrial Development Laboratories and re-equipping the workshops of the Dominion Physical Laboratory and is negotiating with the University of Canterbury on the future work of its Industrial Development Department.

Of the total vote of $£ 2,192,000$ in $196 \mathrm{I}-62, £ 225,000$ was spent on grants to other organizations. The total compares with an average of $£ 1,895,000$ over the three years 1958-61, which represented 0.149 per cent of the gross national product, compared with $0 \cdot 134$ per cent in 1955-58 and 0.154 per cent in 1949-52. The total staff on March 31,1961 , of 1,148 , including 422 scientific officers, increased to 1,170 by the end of the year, including 442 scientific officers. The Council comments on the inadequacy of the amount of capital available for renewal and purchase of scientific equipment and on the demand for research into an ever-increasing number of fields. Grants to research associations in 1961-62 totalled $£ 147,850$, and to Canterbury and Massey Agricultural Colleges and the Industrial Development Department, University of Canterbury, $£ 24,149$, while the Commonwealth Agricultural Bureaux received $£ 18,680$ and the Cawthron Institute $£ 12,400$.

Commenting on the economic value of the Department's research work, the Secretary in his report refers to the importance of the work done on the control of bloat in dairy cattle for which a cheap and efficient method has been found by spraying peanut oil and tallow on the pasture. The discovery by the Entomology Division that 